\title{
Assessing the Continuous Impact of Tributyltin from Antifouling Paints in a Brazilian Mangrove Area Using Intersex in Littoraria angulifera (Lamarck, 1822) as Biomarker
}

\author{
M. B. Costa, ${ }^{1,2}$ G. C. Zamprogno, ${ }^{1,2}$ F. C. Pedruzzi, ${ }^{1,3}$ G. B. Dalbem, ${ }^{1}$ and M. M. P. Tognella ${ }^{2}$ \\ ${ }^{1}$ Biological Sciences Department, Federal University of Espirito Santo, Vitória, ES, Brazil \\ ${ }^{2}$ Center for Human and Natural Sciences, Postgraduate Program in Environmental Oceanography, \\ Federal University of Espirito Santo, Vitória, ES, Brazil \\ ${ }^{3}$ Institute of Oceanography, Postgraduate Program in Coastal Management, Federal University of Rio Grande, \\ Rio Grande, RS, Brazil
}

Correspondence should be addressed to M. B. Costa; merciabc@gmail.com

Received 1 October 2013; Accepted 4 November 2013

Academic Editor: Heinrich Hühnerfuss

Copyright (c) 2013 M. B. Costa et al. This is an open access article distributed under the Creative Commons Attribution License, which permits unrestricted use, distribution, and reproduction in any medium, provided the original work is properly cited.

Intersex is a sensitive biomarker of TBT exposure and effects in littorinid gastropods and described for the mangrove periwinkle Littoraria angulifera for the first time in this study. The objective was to describe the occurrence of intersex in L. angulifera, to propose the species as a sentinel organism to assess TBT contamination, and to characterize the contamination in mangroves. The study was carried out in 2009 by sampling at 20 stations near harbors and marinas and at a reference station on the coast of Espírito Santo Estate, Brazil. At the reference station, no intersex specimens were found, while at 20 sampling stations $51 \%$ of the females exhibited different degrees of intersex development, including the occurrence of functionally sterilized females. The highest incidence of intersex and greatest intersex intensities was found in areas close to marinas and shipyards indicating that vesselrelated activities are still the main source of TBT contamination. L. angulifera collected from stations in areas with well-preserved mangroves was larger than specimens collected from other areas. These differences are attributed to environmental quality and not to occurrence of intersex. The results indicate that this region is still affected by TBT contamination and that L. angulifera has the required sensitivity to be used as a bioindicator.

\section{Introduction}

Estuarine systems are highly complex and dynamic environments due to the spatiotemporal variability of their physicochemical parameters and the influence of a variety of natural and anthropogenic stressors that may affect the health and stability of these ecosystems [1]. However, the effects of stressors and their interaction with individual components of an ecosystem remain unknown [1-3].

Anthropogenic activities in ports, such as shipping and vessel painting and repair, contaminate sediment and the biota. Tributyltin (TBT), a biocide used in marine antifouling paints, contributes to this contamination. TBT exhibits the highest toxicity among organotin compounds (OT) and is considered the most toxic xenobiotic substance deliberately introduced into the environment $[4,5]$.

TBT can cause various negative effects in multiple taxonomic groups, but mollusks are among the most sensitive invertebrates to this substance [6]. To these species, TBT acts as an endocrine disrupter, affecting wild populations of marine gastropods by means of the syndromes called imposex and intersex [7-13].

Imposex is defined as a process of masculinization characterized by development and superimposition of male sexual characteristics (penis and vas deferens) in females. This phenomenon is widely distributed, and currently, approximately 220 known species of neogastropods are affected [14]. 
Imposex is the most widely used biomarker for this type of contamination [15].

Intersex, another important biomarker for TBT was first observed in 1993, on the coast of Germany, when malformations observed in the pallial reproductive tract of the female gastropod Littorina littorea (Linnaeus, 1758) [9, 16] were related to TBT contamination at levels around $10 \mathrm{ng} \mathrm{L}^{-1} \mathrm{Sn}$ [17]. This syndrome is characterized by a phenotypic disorder in the reproductive tract and the gradual transformation of pallial female reproductive organs into male structures which is classified by five morphological stages (Figure 1): Stage 0, normal female without evidence of intersexuality; Stage 1, the female genital opening is enlarged and the proximal bursa copulatrix is divided ventrally; Stage 2 , division of the ventral portion of the pallial oviduct, which exposes the inner lobes; Stage 3, the glands of the pallial oviduct are partially or completely supplanted by a prostate gland; Stage 4, finally, the penis and seminal groove are formed. The females in this state do not exhibit spermiogenesis. According to Bauer et al. [16], in Stages 2-4, the morphological malformation of the oviduct inhibits the formation of capsules and the copulation, which leads to sterilization of females.

After the initial reports on intersex a number of studies were performed $[7-9,11,12,18-21]$, especially in locations where TBT contamination levels are quite high and therefore neogastropod species are not found. The main parameter for quantifying the intensity of intersex in populations is the index of intersex (ISI), calculated as the mean value of each sampled intersex stage proposed by Bauer et al. [16].

Due to the toxic effects of TBT, antifouling paints containing this substance were banned in many countries, but its use persists in many regions of the world, especially in developing countries such as Brazil [22]. In these locations, organotin compounds such as tributyltin are currently being produced and marketed [23]. Recent studies have indicated that these compounds are still being used in some areas and high concentrations of this compound are still found in the environment [24].

Until now, contamination from OTs in Brazil has mainly been studied using imposex in several species of Neogastropods, such as Stramonita haemastoma (Linnaeus, 1758) [25-27], Thais rustica (Lamarck, 1822) [28], Thais deltoidea (Lamarck, 1822) [29], Leucozonia ocellata (Gmelin, 1791), Leucozonia nassa (Gmelin, 1791) (Costa et al., accepted manuscript), and Cymatium parthenopeum parthenopeum (von Salis, 1973) [30], of the order Caenogastropoda.

Caenogastropods are recognized as being less sensitive to contamination by OTs [31, 32], but where neogastropods are not present, such as in mangrove areas, species of Caenogastropods may present an option for monitoring the presence of this contaminant.

Studies investigating OT contamination using bioindicators in mangrove areas in Brazil do not exist, and intersex in Littoraria angulifera (Lamarck, 1822) has not yet been reported. The objective of this study was to investigate the morphological changes caused by TBT in L. angulifera by macroscopic analyses and to conduct spatial monitoring of
TBT contamination using intersex as a biomarker in Victoria Harbor and the Bay of Espírito Santo, southeastern Brazil.

\section{Materials and Methods}

2.1. Study Area. This study was conducted in 2009, around the city of Vitoria and at a reference site (RS) in the city of Serra (Figure 2). The city of Vitoria is highly urbanized and has several ports, including the Port of Tubarão and the Vitoria Port Complex. In addition to these ports, the region includes several marinas that support fishing, recreation, and small vessel maintenance. The reference site was characterized by the lack of apparent OT contamination because all $L$. angulifera specimens collected in this area were free of intersex and all specimens of Leucozonia nassa collected between 2006 and 2012 in this area did not exhibit imposex (Costa et al., accepted manuscript).

2.2. Intersex Analysis. Forty L. angulifera individuals were collected at the reference site (RS) and at each of the 20 sampling stations in the Vitoria Harbor and the Bay of the Espirito Santo region. All specimens measured above $10 \mathrm{~mm}$ and were considered sexually mature. The sample size and sexual maturity were selected according to De Wolf et al. [11]. The animals were transported to the laboratory, kept in tanks containing a 1:1 ratio of seawater to distilled water, and were anesthetized in a $4 \% \mathrm{MgCl}_{2}$ solution. Measurements of shell length $(\mathrm{mm})$ were taken with a Mytutoyo caliper. The shells were broken and the snails analyzed under a stereomicroscope. The sex ratio $(\mathrm{M}: \mathrm{F})$ was determined according to Birchenough et al. [33] for all stations. Values less than 1 indicate a shift of the sex ratio in favor of females, values greater than 1 in favor of males. The percentage or incidence of intersex was calculated by the proportion of females with masculine features, and the intersex index (ISI) was determined according to $[9,16]$ considering the five stages proposed by these authors.

2.3. Littoraria angulifera. L. angulifera (Figure 3(a)) is a tropical littorinid species found almost exclusively in mangroves. This species has separate sexes (Figures 3(b) and 3(c)) and is ovoviviparous with a planktotrophic larval stage [34]. Adults are found on the upper shore zone on the trunks, roots, and leaves of mangrove trees. The species is also found on artificial substrate or rocky shores, where they feed on fungi and algae. The normal structure of the genital system in L. angulifera is documented in Merkt and Ellison [35].

2.4. Data Analysis. The Kruskal-Wallis test was used to compare the values of the ISI at each sampling area. The test of multiple comparisons was performed a posteriori. Correlations between percentage of intersex and ISI average were tested using the Spearman test.

An analysis of variance (two-way ANOVA) was conducted to compare the values of shell length between sampling areas and between the sexes. Subsequently, the Tukey test was used as posttest. Conditions of normality 
0

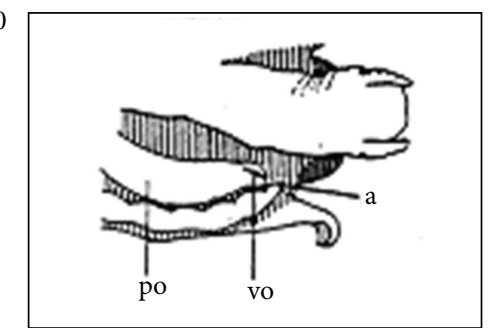

1

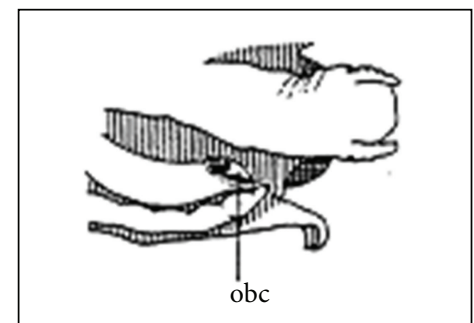

2

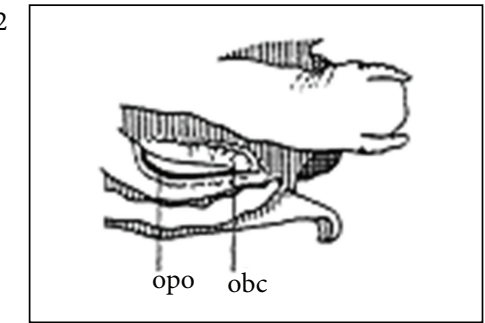

3

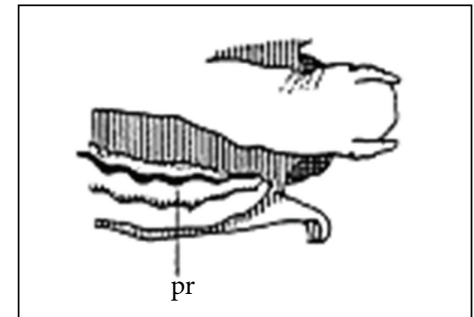

4

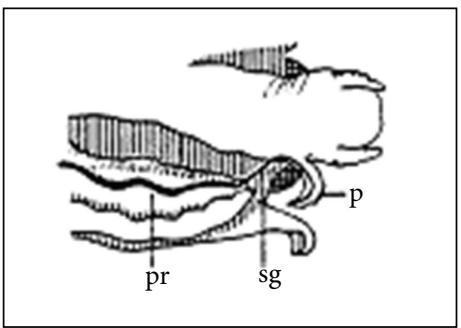

(a)
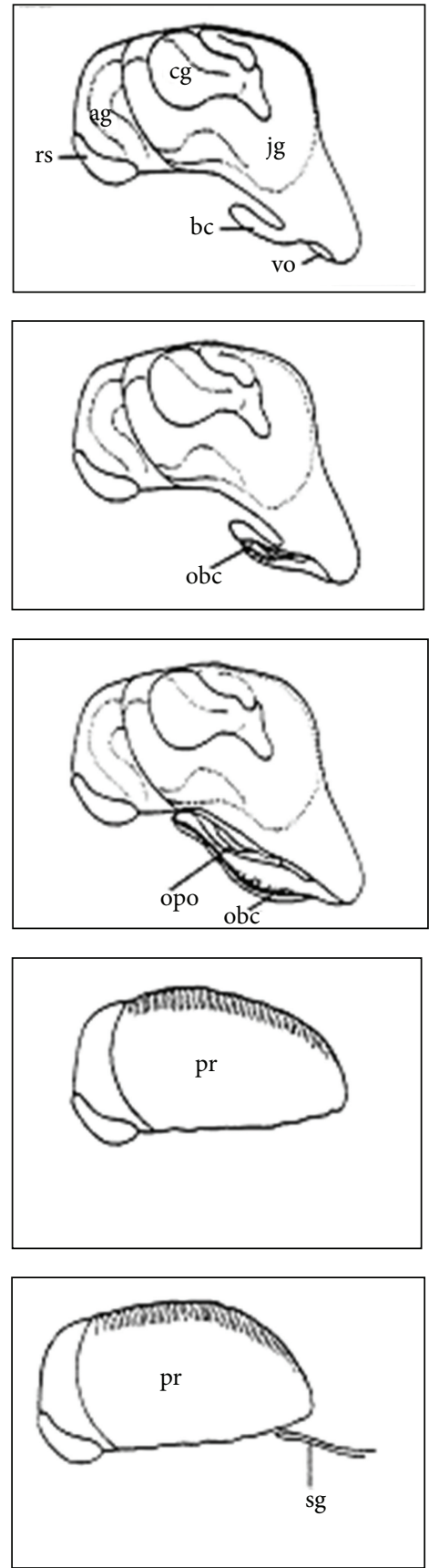

(b)

FIGURE 1: Development scheme for intersex in Littorina littorea with four different stages. Dorsal views with opened mantle cavity (a) and lateral views of pallial genital tract (b). Abbreviations a: anus; ag: albumen gland; bc: bursa copulatrix; cg: capsule gland; ig: albumen gland; obc: open bursa copulatrix; opo: open pallial oviduct, p: penis; po: pallial oviduct; pr: prostate; rs: receptaculum seminis; sg: seminal groove; vo: vaginal opening (source: [9]).

and homogeneity were tested prior to analysis using the Kolmogorov-Smirnov and Levene tests, respectively.

\section{Results and Discussion}

Intersex and other morphometrical parameters are summarized in Table 1. In this study, we collected a total of 759 specimens of $L$. angulifera. At the reference site (RS), no intersex females were found. Of the total of 367 females collected at 20 sampling sites, $51 \%$ exhibited intersex. One intersex female in stage 3 can be seen in Figure 3(d). At Site 1 , where a shipyard for the maintenance of small vessels is located, no specimens were found, despite the presence of small mangrove trees of the species Laguncularia racemosa. 

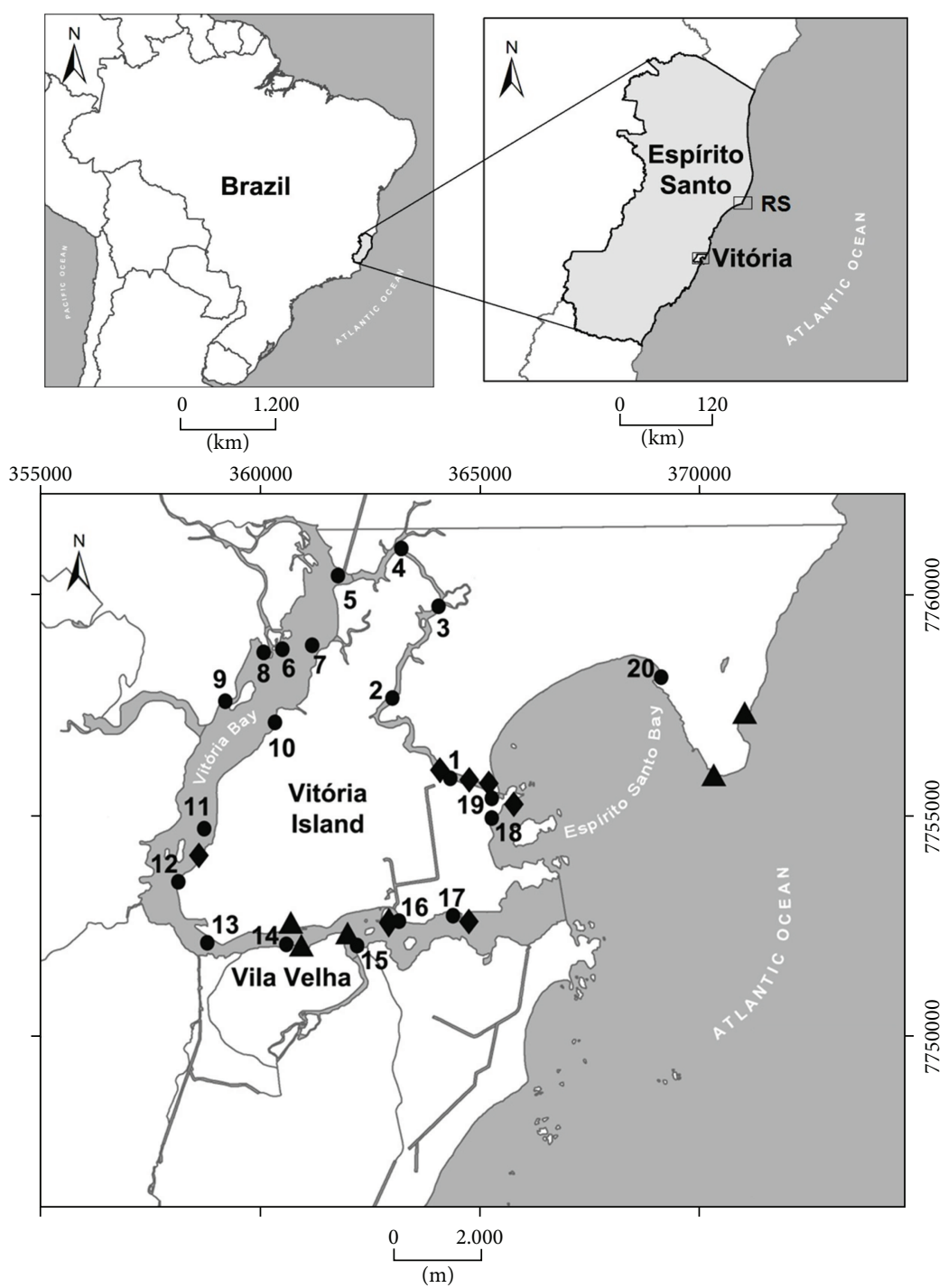

- Sites TBT sources

A Harbors

Marinas

FIGURE 2: Location of the study areas where L. angulifera was collected for analysis of intersex. Potential sources of contamination with organotin compounds are represented. RS: reference site.

3.1. Sex Ratio in the Study Areas. At the reference site, 40 individuals were collected, 24 females and 16 males. The sex ratio was 0.65 , indicating a slight prevalence of females according to [33]. Female-dominated sex ratios were also observed at sites $2,3,5,6,11,12,14,17,18$, and 20 . At other sites, there was a male-biased sex ratio, and site 7 had the highest number of males compared to females $(3: 1)$ (Table 1$)$. The sex ratio found for L. littorea $(1: 1)$ in [17] differs from that found in this study for L. angulifera.

3.2. Intersex Index. The highest intersex incidences (Figure 4) were found in areas close to ports, marinas, and shipyards for the maintenance of small vessels (sites 2, 17, 18, 19, and 20). This finding indicates that vessels in these areas continue to use antifouling paints based on TBT. Similar results were found by Oehlmann et al. [36], Morcillo et al. [37], and De Wolf et al. [11], who observed a high input of TBT in harbor areas.

At sites 6, 11, 15, and 16 no intersex affected specimens were found. These results can be explained by the fact that these sites are located along the Victoria Harbor in areas with water depths that may prevent the snails from coming into direct contact with the sediment. Once released into the water, OTs pass quickly to the particulate phase and tend to accumulate in sediments [38].

Site 20, located in a port area, features a grove of mangroves. Thus, individuals have contact with the sediment, which may explain the high levels of intersex at that site. At sites 5-12, located in mangroves in Victoria Bay, intersex incidences were quite variable in healthy populations (sites 6 


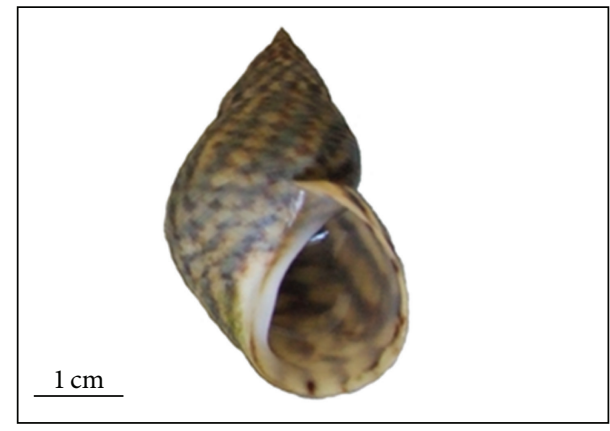

(a)

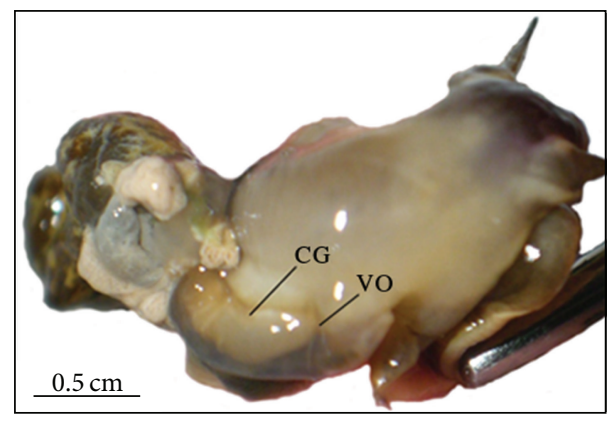

(c)

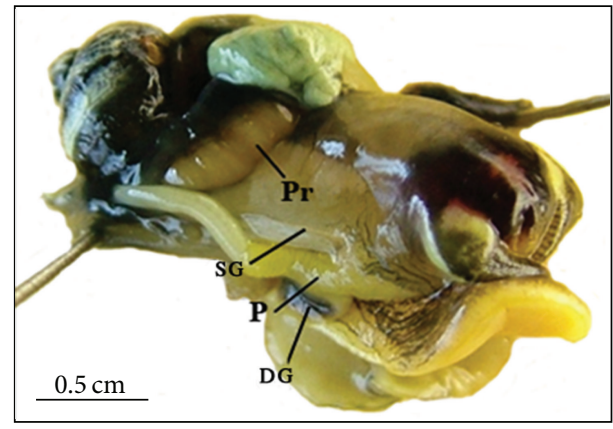

(b)

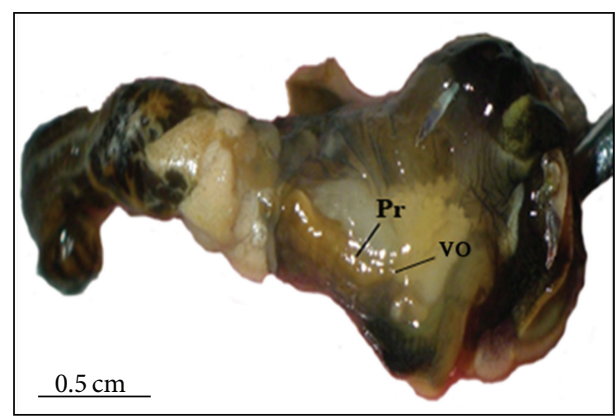

(d)

FIgURE 3: Specimens of L. angulifera. (a) Shell; (b) male, shell removed; (c) normal female, shell removed; (d) intersex female in stage 3, shell removed; CG: capsule gland; VO: vaginal opening; Pr: prostate; SG: seminal groove; P: penis; DG: discoidal gland.

TABLE 1: Results obtained for Littoraria angulifera to the sites. Sex ratio = no. male/no female; ISI: intersex index. (RS: reference site).

\begin{tabular}{|c|c|c|c|c|c|c|}
\hline Sites & No. female & No. male & Sex ratio & \% Intersex & ISI average & Shell length $(\mathrm{mm})$ \\
\hline 1 & 0 & 0 & - & - & - & - \\
\hline 2 & 11 & 10 & 0.91 & 90.91 & 2.72 & $30.10 \pm 2.68$ \\
\hline 3 & 25 & 15 & 0.60 & 8.00 & 2.00 & $31.17 \pm 3.93$ \\
\hline 4 & 16 & 22 & 1.38 & 6.25 & 2.00 & $29.17 \pm 2.69$ \\
\hline 5 & 23 & 16 & 0.70 & 34.78 & 2.00 & $28.66 \pm 2.89$ \\
\hline 6 & 22 & 18 & 0.82 & 0.00 & - & $27.51 \pm 2.32$ \\
\hline 7 & 10 & 30 & 3.00 & 50.00 & 2.00 & $27.70 \pm 2.34$ \\
\hline 8 & 19 & 21 & 1.11 & 31.58 & 2.00 & $29.10 \pm 1.81$ \\
\hline 9 & 16 & 24 & 1.50 & 37.50 & 2.65 & $26.99 \pm 2.99$ \\
\hline 10 & 17 & 23 & 1.35 & 35.29 & 2.00 & $23.25 \pm 3.03$ \\
\hline 11 & 25 & 15 & 0.60 & 0.00 & - & $19.11 \pm 2.43$ \\
\hline 12 & 23 & 17 & 0.74 & 17.39 & 2.00 & $20.23 \pm 1.67$ \\
\hline 13 & 16 & 18 & 1.13 & 18.75 & 2.00 & $14.75 \pm 2.09$ \\
\hline 14 & 21 & 15 & 0.71 & 9.52 & 2.00 & $14.67 \pm 2.56$ \\
\hline 15 & 17 & 17 & 1.00 & 0.00 & - & $19.12 \pm 3.98$ \\
\hline 16 & 17 & 20 & 1.18 & 0.00 & - & $20.97 \pm 2.20$ \\
\hline 17 & 21 & 19 & 0.90 & 71.43 & 2.00 & $21.44 \pm 2.15$ \\
\hline 18 & 21 & 19 & 0.90 & 85.71 & 2.00 & $24.27 \pm 1.57$ \\
\hline 19 & 20 & 20 & 1.00 & 85.00 & 3.00 & $19.44 \pm 2.19$ \\
\hline 20 & 27 & 13 & 0.48 & 81.48 & 3.00 & $23.11 \pm 2.71$ \\
\hline RS & 24 & 16 & 0.65 & 0.00 & - & $21.22 \pm 3.44$ \\
\hline
\end{tabular}


TABLE 2: Results of two-way ANOVA analysing shell lengths between sampling sites and sex. $F$ : test value. $P$ : probability for $\alpha$ error.

\begin{tabular}{lccccc}
\hline Variable & Source of variation & Degrees of freedom & $F$ & $P$ & Tukey \\
\hline \multirow{3}{*}{ Shell lenght } & Sites & 19 & 136.48 & $<0.001$ & $2-8>9-12,15-20$, PC $>13,14$ \\
& Sex & 1 & 45.28 & $<0.001$ & Female $>$ Male \\
& Sites $\times$ sex & 9 & 63277.11 & $<0.001$ & - \\
\hline
\end{tabular}

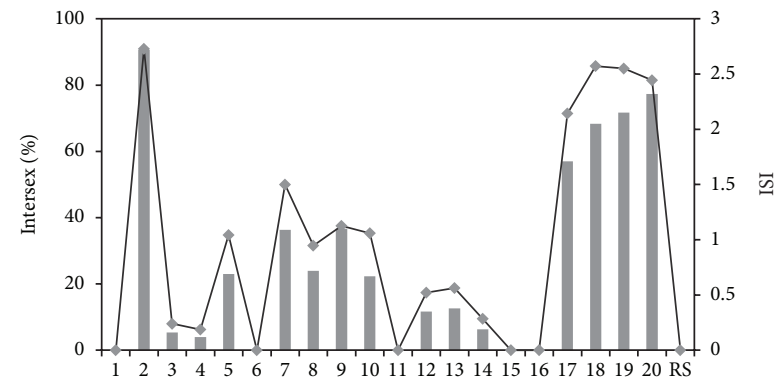

FIGURE 4: Percentage of intersex and ISI values medium obtained in the sample points. RS: reference site.

and 11 ) and reached a maximum of $50 \%$ at site 7 . The distance from the main sources of TBT may have contributed to these results; however, the presence of small harbors in the region may explain the occurrence of intersex at some of these sites.

The intersex stages varied between 0 and 3 . Sites 2,17 , 18, 19, and 20 showed the highest ISI values (Figure 4). Significant differences were found between these sites and others (posttest multiple comparisons Kruskal-Wallis value: 230.67, $P<0.001)$. All intersex females were sterile because, according to Bauer et al. [16], the intersex stage 2 is characterized by a morphological malformation of the oviduct which inhibits the formation of the capsule and a successful copulation. In stage 3 (found at sites 2, 9, and 1720 ), a complete replacement of the capsule gland by a prostate prevents formation and nutrition of extraembryonic eggs capsules and eggs, leading to reproductive failure [9]. The occurrence of these stages indicates that these populations have ceased breeding.

The highest ISI values found in this study (ISI 3.0) are similar to those found for L. littorea by Bauer et al. [9] (ISI > 3.0) and Van Den Broeck et al. [20] (3.52 ISI) and are higher than reported ISI values for the same species collected in Portugal (ISI 0.5) [39] and Ireland (ISI 1.30) [8] in port areas.

We obtained a positive correlation between the ISI value and intersex incidence (Figure 5). Thus, the results indicate that both indices are sufficiently sensitive to assess the level of contamination by TBT and its consequences for the population. However, according to Bauer et al. [9], ISI is a more suitable index than the percentage of intersex when assessing the reproductive capacity of a population because the ISI evaluates the percentage of sterility.

3.3. Length of Shells. Regarding the length of the shells, animals collected at sites $2-8$, located in the most pristine mangrove areas, showed higher values compared to those recorded at other sampling points. It is possible that the better

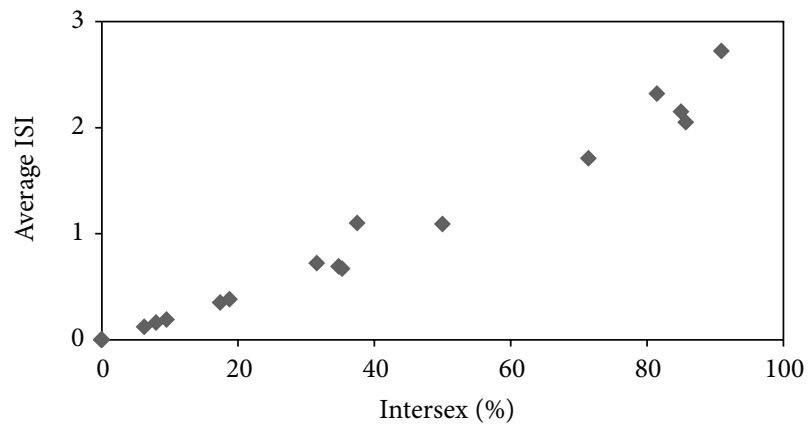

FIGURE 5: Correlation between values of intersex (\%) and average ISI. Results of the Spearman test: $r=0.98, P<0.05$.

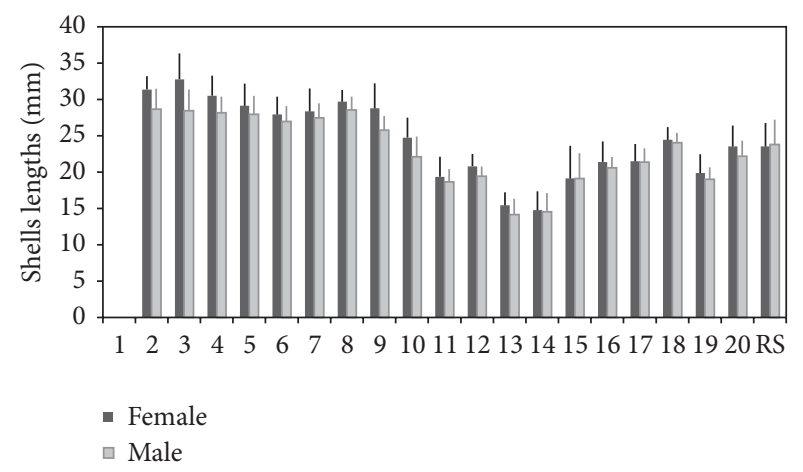

FIgURE 6: Distribution of length values shells of L. angulifera collected in the sampling areas. RS: reference site.

condition of that ecosystem, as indicated by more developed trees and greater availability of substrate and food for $L$. angulifera, may have contributed to this result, as the individuals were smaller (Figure 6, Table 2) in the areas where the mangrove forest was not present (sites 10-20).

At the reference site, individuals also had smaller shells. This area is located in a grove of mangroves established on ferruginous laterites, on a beach away from the estuary, and is composed of less-developed trees compared with those of the mangrove estuary in Victoria Harbor. Merkt and Ellison [35] attributed variations in the morphology of L. angulifera shells to differences in habitat caused by nutritional conditions, local climate, forest structure, and geomorphology. These authors found that the specimens located in mangroves established on carbonate platforms are smaller due to the oligotrophic nature of these features when compared with those found in estuarine mangroves. Lower food availability and higher salinity can result in slower growth rates of L. angulifera [35], which may explain the differences in shell 
length found in this study between the estuarine mangrove areas and other areas, such as consolidated substrate and artificial beach.

Unlike the results obtained in this study, Van Den Broeck et al. [20] found shells to be larger and heavier in places more severely affected by TBT, attributing their findings to population demographics or energy allocation to growth due to TBT. When comparing the sample areas, there was no apparent influence of TBT on shell size in our study. However, when comparing the length of shells of intersex females $(25.1 \pm 4.9$, mean \pm standard deviation), it was observed that intersex-free females were smaller $(23.7 \pm 6.0$, mean \pm standard deviation) (ANOVA, $P=0.03$ ), indicating a possible influence of TBT.

With respect to sex differences females had significantly larger shells than males (Figure 6, Table 2). Similar results were found by Van Den Broeck et al. [20] for Littorina littorea.

\section{Conclusions}

Neogastropods are generally more sensitive to TBT than Caenogastropods [32], but some Caenogastropods such as Cymatium p. parthenopheum can be used as indicators of OTs [30], especially in areas with high levels of TBT contamination.

Littorinid species are more tolerant to high levels of TBT [18]; however, the results obtained in this study indicate that $L$. angulifera is also a sensitive bioindicator and can be used as a sentinel species for monitoring such compounds, especially in regions where Neogastropods are not present, such as mangrove forests, or areas with considerably higher levels of TBT. Moreover, being a widely distributed and easily accessible species makes them an excellent choice for monitoring TBT contamination in mangrove areas.

The results obtained in this study, revealing high levels of intersex, indicate that the Vitória Bay and the Espirito Santo Bay are being negatively affected by the presence of OTs. However, in port areas with artificial substrates and greater depths that prevent contact between animals and sediment, levels of intersex obtained for this species may not match the levels of contamination at the site.

\section{References}

[1] R. J. O'Connor, "Toward the incorporation of spatiotemporal dynamics into ecotoxicology," in Population Dynamics in Ecological Space and Time, O. E. Rhodes, R. K. Chesser, and M. H. Smith, Eds., pp. 281-317, University of Chicago Press, Chicago, Ill, USA, 1996.

[2] D. Connell, P. Lam, B. Richardson, and R. Wu, Introduction to ecoToxicology, Blackwell Science, Oxford, UK, 1999.

[3] M. A. Champ, "Marine Testing Board for certification of ballast water treatment technologies," Marine Pollution Bulletin, vol. 44, no. 12, pp. 1327-1335, 2002.

[4] M. D. Muller, L. Renberg, and G. Rippen, "Tributyltin in the environment-sources, fate and determination. An assessment of present status and research needs," Chemosphere, vol. 18, no. 9-10, pp. 2015-2042, 1989.
[5] C. Stewart, S. J. De Mora, M. R. L. Jones, and M. C. Miller, "Imposex in New Zealand neogastropods," Marine Pollution Bulletin, vol. 24, no. 4, pp. 204-209, 1992.

[6] G. W. Bryan and P. E. Gibbs, "Impact of low concentrations of tributyltin (TBT) on marine organisms: a review," in Metal Ecotoxicology Concepts and Applications, M. C. Newman and A. W. McIntosh, Eds., pp. 323-361, Lewis, 1991.

[7] D. Minchin, E. Stroben, J. Oehlmann, B. Bauer, C. B. Duggan, and M. Keatinge, "Biological indicators used to map organotin contamination in Cork Harbour, Ireland," Marine Pollution Bulletin, vol. 32, no. 2, pp. 188-195, 1996.

[8] D. Minchin, B. Bauer, J. Oehlmann, U. Schulte-Oehlmann, and C. B. Duggan, "Biological indicators used to map organotin contamination from a fishing port, Killybegs, Ireland," Marine Pollution Bulletin, vol. 34, no. 4, pp. 235-243, 1997.

[9] B. Bauer, P. Fioroni, U. Schulte-Oehlmann, J. Oehlmann, and W. Kalbfus, "The use of Littorina littorea for tributyltin (TBT) effect monitoring-results from the German TBT survey 1994/1995 and laboratory experiments," Environmental Pollution, vol. 96, no. 3, pp. 299-309, 1997.

[10] P. Matthiessen and P. E. Gibbs, "Critical appraisal of the evidence for tributyltin-mediated endocrine disruption in mollusks," Environmental Toxicology and Chemistry, vol. 17, pp. 3743, 1998.

[11] H. De Wolf, W. De Coen, T. Backeljau, and R. Blust, "Intersex and sterility in the periwinkle Littorina littorea (Mollusca: Gastropoda) along the Western Scheldt estuary, the Netherlands," Marine Environmental Research, vol. 52, no. 3, pp. 249-255, 2001.

[12] H. Van den Broeck, H. De Wolf, T. Backeljau, and R. Blust, "Effects of environmental stress on the condition of Littorina littorea along the Scheldt estuary (The Netherlands)," Science of the Total Environment, vol. 376, no. 1-3, pp. 346-358, 2007.

[13] J. Oehlmann, P. Di Benedetto, M. Tillmann, M. Duft, M. Oetken, and U. Schulte-Oehlmann, "Endocrine disruption in prosobranch molluscs: evidence and ecological relevance," Ecotoxicology, vol. 16, no. 1, pp. 29-43, 2007.

[14] C. P. Titley-O’Neal, K. R. Munkittrick, and B. A. MacDonald, "The effects of organotin on female gastropods," Journal of Environmental Monitoring, vol. 13, no. 9, pp. 2360-2388, 2011.

[15] A. Sousa, F. Laranjeiro, S. Takahashi, S. Tanabe, and C. M. Barroso, "Imposex and organotin prevalence in a European post-legislative scenario: temporal trends from 2003 to 2008," Chemosphere, vol. 77, no. 4, pp. 566-573, 2009.

[16] B. Bauer, P. Fioroni, I. Ide et al., "TBT effects on the female genital system of Littorina littorea: a possible indicator of tributyltin pollution," Hydrobiologia, vol. 309, no. 1-3, pp. 15-27, 1995.

[17] H. De Wolf, C. Handa, T. Backeljau, and R. Blust, "A baseline survey of intersex in Littorina littorea along the Scheldt estuary, The Netherlands," Marine Pollution Bulletin, vol. 48, no. 5-6, pp. 592-596, 2004.

[18] J. Oehlmann, B. Bauer, D. Minchin, U. Schulte-Oehlmann, P. Fioroni, and B. Markert, "Imposex in Nucella lapillus and intersex in Littorina littorea: interspecific comparison of two TBT-induced effects and their geographical uniformity," Hydrobiologia, vol. 378, pp. 199-213, 1998.

[19] G. Sundermann, B. Bauer, and J. Oehlmann, "Ultrastructure of prostate gland tissue in males and females with intersex phenomena of Littorina littorea L," Hydrobiologia, vol. 378, no. 1-3, pp. 227-233, 1998. 
[20] H. Van den Broeck, H. De Wolf, T. Backeljau, and R. Blust, "Comparative assessment of reproductive impairment in the gastropod mollusc Littorina littorea along the Belgian North Sea coast," Science of the Total Environment, vol. 407, no. 8, pp. 30633069, 2009.

[21] J. Rank, "Intersex in Littorina littorea and DNA damage in Mytilus edulis as indicators of harbour pollution," Ecotoxicology and Environmental Safety, vol. 72, no. 4, pp. 1271-1277, 2009.

[22] D. M. Santos, B. S. Sant'anna, A. F. L. Godoi, A. Turra, and M. R. R. Marchi, "Contamination and impact of organotin compounds on the Brazilian coast," in Pollution Monitoring, A. C. Ortiz and N. B. Griffn, Eds., pp. 31-59, Science, Hauppauge, NY, USA, 2011.

[23] Í. B. De Castro, F. C. Perina, and G. Fillmann, "Organotin contamination in South American coastal areas," Environmental Monitoring and Assessment, vol. 184, no. 3, pp. 1781-1799, 2012.

[24] B. S. Sant’anna, Assimilação, depuração, e contaminação do ermitão Clibanarius vittatus pelo poluente tributilestanho (TBT) e sua relação com a intersexualidade em ermitões [Ph.D. thesis], Universidade Estadual Paulista, São Paulo, Brazil, 2011.

[25] I. B. Castro, H. M. Cascan, and M. A. Fernandez, "Imposex em Thais haemastoma (Linnaeus, 1767) (Mollusca: Gastropoda) uma indicação da contaminação por organoestânicos na costa do município de Fortaleza-Ceará-Brasil," Arquivos De Ciências Do Mar, vol. 33, pp. 51-56, 2000.

[26] M. A. Fernandez, A. D. L. R. Wagener, A. M. Limaverde, A. L. Scofield, F. M. Pinheiro, and E. Rodrigues, "Imposex and surface sediment speciation: a combined approach to evaluate organotin contamination in Guanabara Bay, Rio de Janeiro, Brazil," Marine Environmental Research, vol. 59, no. 5, pp. 435452, 2005.

[27] M. A. Fernandez, F. M. Pinheiro, J. P. de Quadros, and E. Camillo Jr., "An easy, non-destructive, probabilistic method to evaluate the imposex response of gastropod populations," Marine Environmental Research, vol. 63, no. 1, pp. 41-54, 2007.

[28] I. B. Castro, C. A. O. Meirelles, H. Matthews-Cascon, and M. A. Fernandez, "Thais (Stramonita) rustica (Lamarck, 1822) (Mollusca: Gastropoda: Thaididae), a potential bioindicator of contamination by organotin northeast Brazil," Brazilian Journal of Oceanography, vol. 52, pp. 101-105, 2004.

[29] M. B. da Costa, M. A. Fernandez, D. C. Barbiero, F. T. V. de Melo, M. B. P. Otegui, and B. S. Ferreira, "First record of imposex in Thais deltoidea (Lamarck, 1822) (Mollusca, Gastropoda, Thaididae) in Vitória, ES, Brazil," Brazilian Journal of Oceanography, vol. 56, no. 2, pp. 145-148, 2008.

[30] M. B. Costa, M. B. P. Otegui, D. C. Barbiero, and M. A. S. Fernandez, "Cymatium parthenopeum parthenopeum (von Salis, 1793) (Caenogastropoda: Ranellidae): a new bioindicator of organotin compounds contamination?" Journal of the Brazilian Society of Ecotoxicology, vol. 3, no. 1, pp. 65-69, 2008.

[31] B. P. Mensink, H. Kralt, A. D. Vethaak et al., "Imposex induction in laboratory reared juvenile Buccinum undatum by tributyltin (TBT)," Environmental Toxicology and Pharmacology, vol. 11, no. 1, pp. 49-65, 2002.

[32] Y. Vishwakiran, A. C. Anil, K. Venkat, and S. S. Sawant, "Gyrineum natator: a potential indicator of imposex along the Indian coast," Chemosphere, vol. 62, no. 10, pp. 1718-1725, 2006.

[33] A. C. Birchenough, N. Barnes, S. M. Evans, H. Hinz, I. Krönke, and C. Moss, "A review and assessment of tributyltin contamination in the North Sea, based on surveys of butyltin tissue burdens and imposex/intersex in four species of neogastropods," Marine Pollution Bulletin, vol. 44, no. 6, pp. 534-543, 2002.

[34] S. B. Gallagher and G. K. Reid, "Population dynamics and zonation of the periwinkle snail, Littorina angulifera, of the Tampa Bay, Florida, region," Nautilus, vol. 94, pp. 162-178, 1979.

[35] R. E. Merkt and A. Ellison M, "Geographic and habitat-specific morphological variations of littoraria (Littorinopsis) Angulifera (Lamarck, 1822)," Malacologia, vol. 40, no. 1-2, pp. 279-295, 1998.

[36] J. Oehlmann, P. Fioroni, E. Stroben, and B. Markert, “Tributyltin (TBT) effects on Ocinebrina aciculata (Gastropoda: Muricidae): imposex development, sterilization, sex change and population decline," Science of the Total Environment, vol. 188, no. 2-3, pp. 205-223, 1996.

[37] Y. Morcillo, V. Borghi, and C. Porte, "Survey of organotin compounds in the Western Mediterranean using molluscs and fish as sentinel organisms," Archives of Environmental Contamination and Toxicology, vol. 32, no. 2, pp. 198-203, 1997.

[38] W. J. Langsten and N. D. Pope, "Determinants of TBT adsorption and desorption in estuarine sediments," Marine Pollution Bulletin, vol. 31, no. 1-3, pp. 32-43, 1995.

[39] C. M. Barroso, M. H. Moreira, and P. E. Gibbs, "Comparison of imposex and intersex development in four prosobranch species for TBT monitoring of a southern European estuarine system (Ria de Aveiro, NW Portugal)," Marine Ecology Progress Series, vol. 201, pp. 221-232, 2000. 

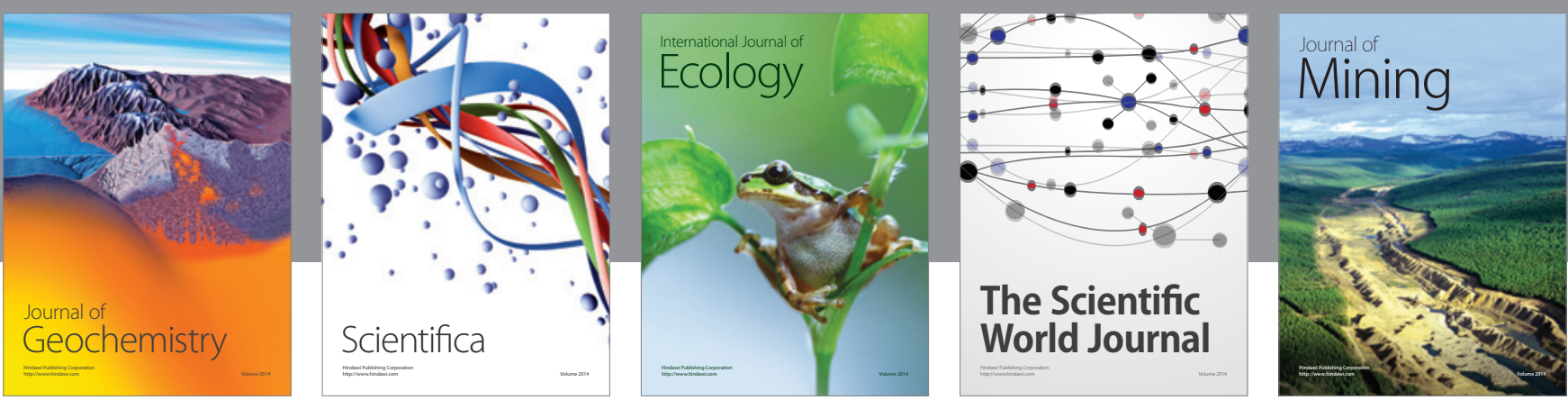

The Scientific World Journal
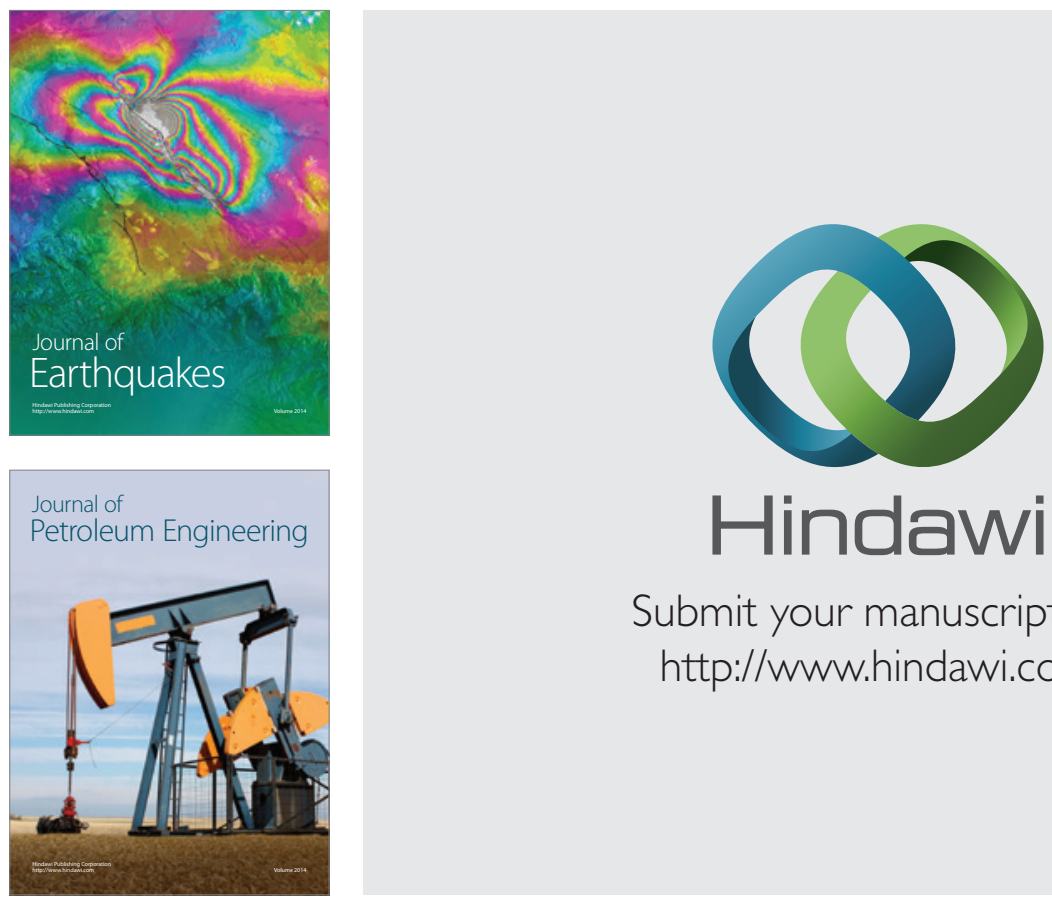

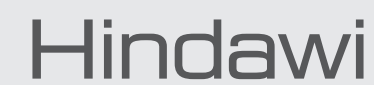

Submit your manuscripts at

http://www.hindawi.com
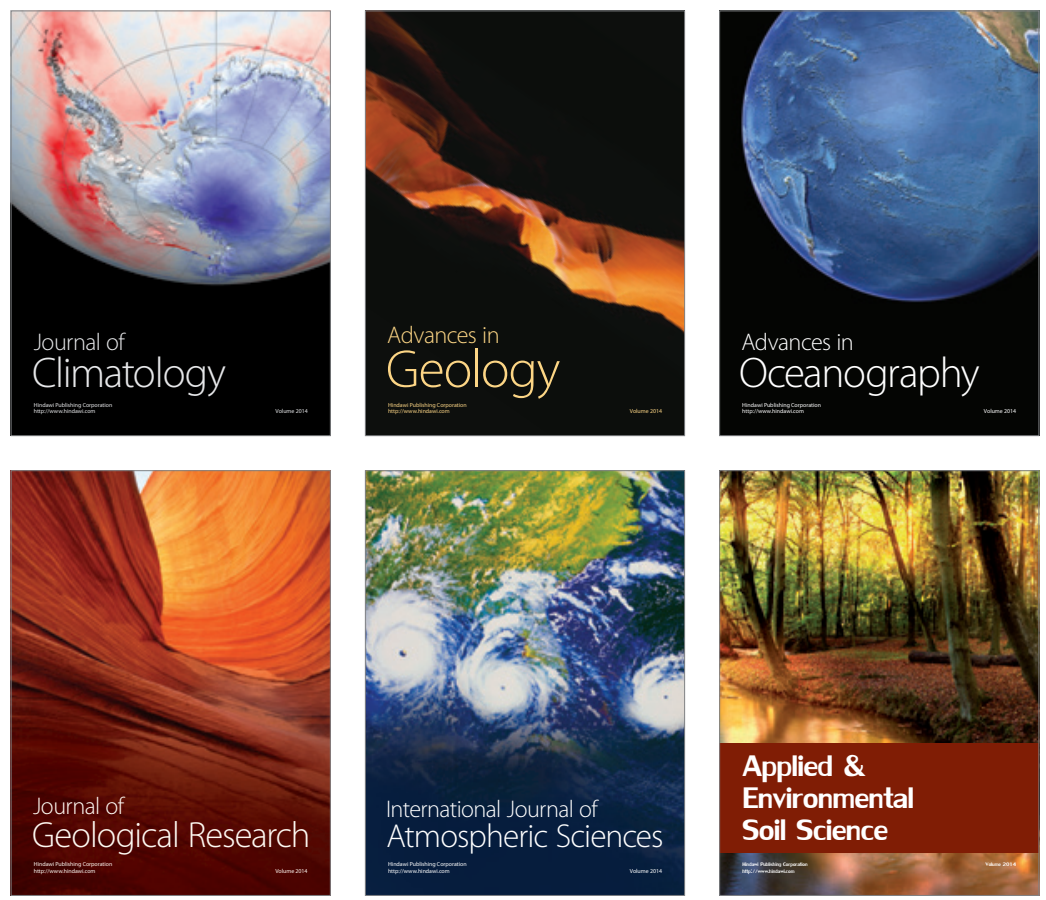
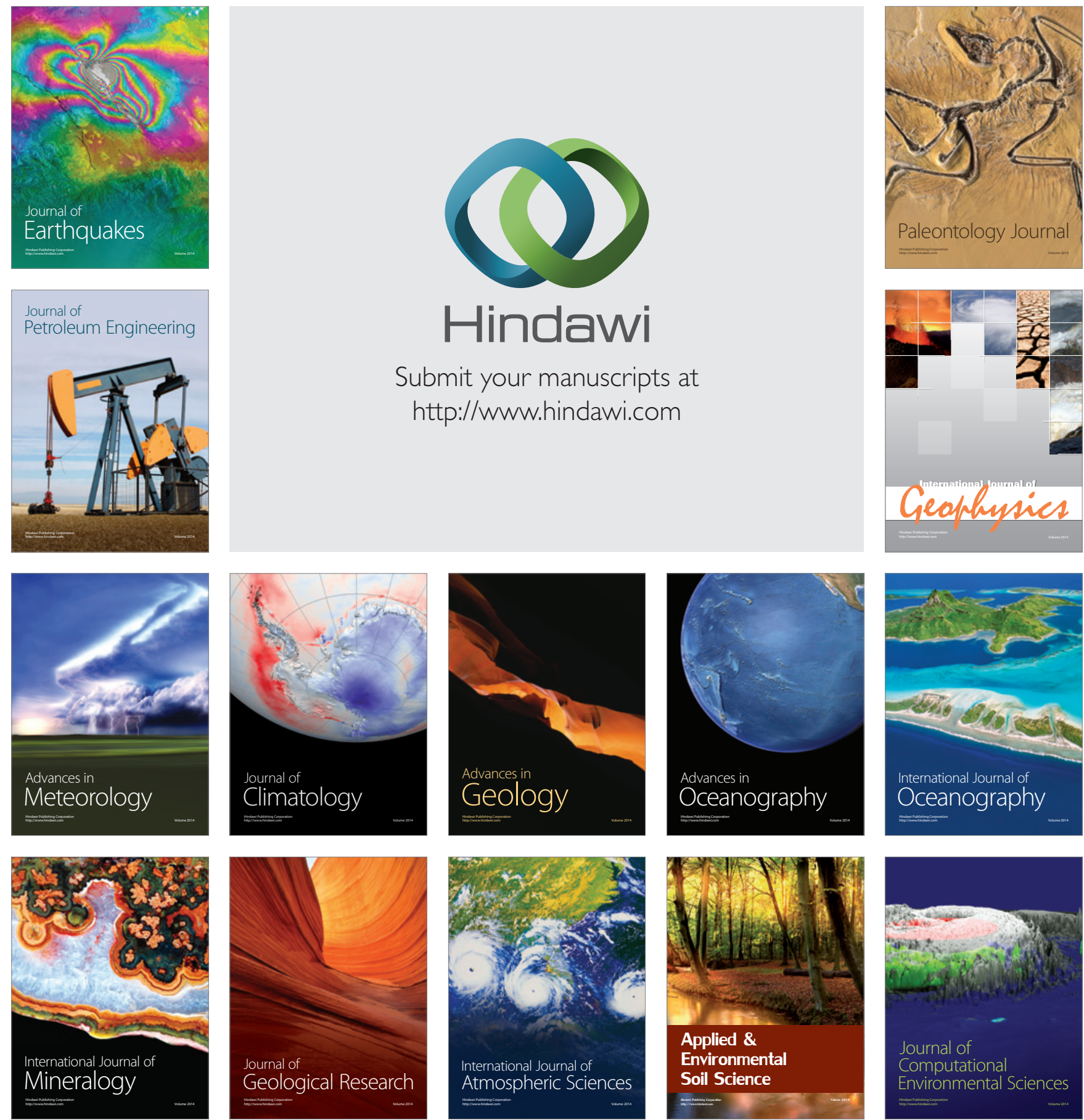